\title{
Flipped Classroom Learning Combined with Google Classroom and Video Conference to Improve Students' Learning Independent and Mathematics Learning Outcomes
}

\author{
I Putu Pasek Suryawan ${ }^{1 *}$, Kadek Ayu Mutiara Pratiwi², I Gusti Putu Suharta ${ }^{3}$ D
e-mail: putu.pasek@undisha.ac.id
e-matics Education Study Program, Ganesha University of Education
}

\section{A R T I CLE I N F O}

Article history:

Received May 14, 2021

Revised may 17, 2021

Accepted June 09, 2021

Available online August 25, 2021

\section{Kata Kunci:}

Video Conference, Kemandirian belajar, Hasil belajar

Keywords:

Video Conference, Independent

Learning, Learning Outcomes

DOI:

https://dx.doi.org/10.23887/jet.v5 i3.34466

\begin{abstract}
A B S T R A K
Pemilihan strategi belajar yang kurang tepat akan membuat suasana belajar menjadi tidak menyenangkan bagi siswa. Hal ini akan berdampak pada hasil belajar siswa yang rendah. Penelitian ini bertujuan untuk menganalisis pembelajaran flipped classroom dengan memanfaatkan google classroom dan video conference. Penelitian pengembangan ini merujuk pada model pengembangan ADDIE yang terdiri atas lima langkah yaitu analyze, design, development, implementation, evaluation. Subjek uji coba penelitian ini adalah tiga orang ahli perangkat pembelajaran dan dua orang ahli media pembelajaran pada tahap validasi serta 32 siswa SMP pada tahap implementasi. Hasil penelitian menunjukkan kevalidan perangkat pembelajaran berada pada kategori sangat layak diimplementasikan dengan persentase rata-rata validitas RPP $88,10 \%$, bahan ajar 90,00\%, instrumen tes $90,48 \%$, dan kevalidan media pembelajaran 90,00\% pada kategori sangat layak diimplementasikan. Kepraktisan pembelajaran flipped classroom dilihat melalui angket respon siswa dengan rata-rata 3,22 berada pada kategori tinggi, dan angket respon guru dengan rata-rata 3,70 berada pada kategori sangat tinggi. Kemandirian belajar mengalami peningkatan, di mana sebelum pembelajaran ratarata 2,49 dengan kategori rendah, dan setelah pembelajaran 2,90 dengan kategori tinggi. Hasil uji gain menunjukkan gain-score 0,44 dengan kategori sedang, sehingga tergolong cukup efektif dalam meningkatkan hasil belajar matematika siswa. Dapat disimpulkan pembelajaran flipped classroom berbantuan google classroom dan video conference efektif dalam meningkatkan kemandirian dan hasil belajar matematika siswa.
\end{abstract}

\section{A B S T R A C T}

The selection of learning strategies that are not appropriate will make the learning atmosphere unpleasant for students. This will have an impact on low student learning outcomes. This study aims to analyze the flipped classroom learning by utilizing google classroom and video conferencing. This development research refers to the ADDIE development model, consisting of five steps: analysis, design, development, implementation, and evaluation. The subjects of this research trial were three learning device experts and two learning media experts at the validation stage, and 32 junior high school students at the implementation stage. The results showed that the validity of the learning tools was in the very feasible category to be implemented with an average proportion of RPP validity $88.10 \%$, teaching materials $90.00 \%$, test instruments $90.48 \%$, and learning media validity $90.00 \%$ in the very feasible category to be implemented. . The practicality of flipped classroom learning is seen through student response questionnaires with an average of 3.22 being in the high category, and the teacher's response questionnaire with an average of 3.70 being in the very high category. Independent learning has increased where before learning, the average is 2.49 in the low category, and after learning 2.90 in the high category. The gain test results show a gain-score of 0.44 in the medium category, so it improves students' mathematics learning outcomes. Can guarantee that flipped classroom learning assisted by google classroom and video conferencing effectively increases students' independence and mathematics learning outcomes.

This is an open access article under the CC BY-SA license.

Copyright (C) 2021 by Author. Published by Universitas Pendidikan Ganesha.

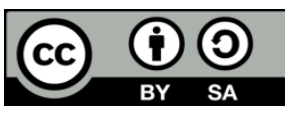

\section{INTRODUCTION}

The era of the 4.0 industrial revolution has influenced the world where the increasing connectivity, interaction, and development of the digital system will certainly also impact the education sector (Mills et al., 2021; Shahroom \& Hussin, 2018). In the field of education in the 4.0 era, it is required to construct learning that involves technology (Indah Septiani et al., 2020; Kergroach, 2017). The term used by education experts to describe how technology is implemented into learning is Education 4.0. Education 4.0 requires teachers to 
master technology to be integrated in the learning process (Anitha Kumari et al., 2020; Fernández-Gutiérrez et al., 2020). Free learning education is a response to the needs of the education system in the era of revolution 4.0, where teachers and students are subjects in the learning system, which means that the position of the teacher in the classroom is not to instill or uniform the truth according to the teacher, but to explore the truth, reasoning power and critically students see world and phenomena (Widiasanti, 2017; Xu et al., 2018).

The era of 4.0 education is required to be more oriented towards self-directing, self-determining, that is, building self-respecting behavior by learning independently to take advantage of unlimited learning resources in terms of content, space, place or time (Bui \& Do Van Dung, 2019; Felver et al., 2016). Learning independence is one important factor in determining student success in learning. By trying alone or independently, students will gain concrete experiences, provide meaning and satisfaction for students (Istikomah \& Usman, 2019; Syahroni et al., 2016). However, in reality, the learning that is currently happening is more teacher-centered (Fakhriyah, 2014; Nuswowati et al., 2017; Wau, 2017). The students become less independent and do not believe in themselves because teachers are more actively involved in learning (Akay \& Kim, 2020; Liu et al., 2021). Conventional learning does have advantages including teachers or lecturers who can directly monitor the learning progress of students, interact and find out the abilities of students. But with conventional learning, students are only fixated on learning resources set by the teacher so that it tends to be unpleasant for students (Irodah et al., 2020; Yigzaw et al., 2019). In learning mathematics, choosing the right learning strategy will affect students' mathematics learning outcomes. This is supported by research which results in a significant effect of learning strategies on mathematics learning outcomes (Hobri et al., 2018; Stojanović et al., 2021). So that the selection of the right learning strategy that is in accordance with the revolutionary era 4.0 is very much needed in supporting the concept of independent learning which will affect the independence and learning outcomes of students' mathematics.

In the era 4.0 technological developments provide opportunities to learn even though they are separated by place and time and there is no face to face, one of the learning methods that can be applied is blended learning (Dziuban et al., 2018; Prasasti et al., 2019). Blended learning is a learning model that integrates face-to-face learning with e-learning that takes advantage of advances in innovation and technology offered (Fitriyana et al., 2020; Sefriani et al., 2021). There are types of blended learning, one of which is flipped classroom. Flipped classroom is a learning strategy that uses a type of blended learning approach by reversing the traditional learning environment and providing learning content outside the classroom (mostly online) (Anjelina \& Mawardi, 2021; Lin et al., 2021). Broadly speaking, the implementation of this model begins with online home learning. In online learning, teachers use the help of certain applications to provide teaching materials that students will learn independently. Furthermore, during face-to-face learning at school, the teacher facilitates and guides students to deepen the learning concepts that students have learned at home by intensifying the provision of problem-based exercises and project work (Van Alten et al., 2019; Widyaningrum et al., 2020).

The flipped classroom learning strategy is one of the learning strategies that can be used to assist students in learning which provides opportunities for students to build their own knowledge and provides opportunities for students to develop their potential (Leatherman \& Cleveland, 2020; Yen, 2020). Teaching flipped classroom models encourage students to watch videos, view material, and do assignments in teaching in their own time and form the concept of learning done at home. To implement the flipped classroom learning strategy, learning media are needed that support student learning independently at home (Qingqing, 2016; Zainuddin \& Perera, 2019). The use of video media is the right choice, if students do not understand, students can replay the video several times, considering that each student's ability to understand the material is different, video learning will improve student understanding through audio and visual (Gabriele et al., 2016; Satyawan, 2018).

In addition to learning media, flipped classroom learning requires virtual classes to support students' online learning independently, teachers can take advantage of the various LMS available, one of which is Google Classroom (Albashtawi \& Al Bataineh, 2020; Subandi et al., 2018). With the help of Google Classroom, teachers can create their virtual classes to carry out online learning and upload instructional materials in which there are learning resources for students to learn independently while at home (Ahmed \& Indurkhya, 2020; Kurniawati et al., 2019). Google classroom is effectively used as a virtual class during the Covid-19 pandemic (Guswara, 2020). As a result of the Covid-19 period, learning was carried out using online or distance learning methods so that there was no face-to-face at school. However, in flipped classroom learning, face-to-face learning can be transferred to face-to-face virtually, namely through a video conference platform. Video conference can be used to support learning, a tool form two way communication in different place, arranging learning activities, and an a tool in collaborative learning (Nonthamand, 2020).

So based on the explanation above the urgency of this research is the importance of student learning independence in the era of revolution 4.0 and pandemic covid 19 which resulted in teachers needing to choose learning strategies that utilize technology optimally so as to increase the understanding of students that will also have an impact on improving students' math learning outcomes (Adedoyin \& Soykan, 2020; Jogezai et al., 
2021). Some of the research results show positive results on the use of flipped classroom learning strategies for independence and student learning outcomes. The results of this study are that there are differences learning outcomes between students taught using the flipped classroom strategy and students taught using conventional learning strategies (Li et al., 2018; Van Alten et al., 2019). The effect of using the flipped classroom learning model can improve student learning outcomes (Foldnes, 2016; Kurtz et al., 2014). The shortcomings of previous research were to measure only one variable, but this research measured two variables at once, namely independence and the results of students' math learning. In addition, in previous research less optimize technology in the media to accommodate the learning style of students. Based on the explanation above, to improve the independence and learning outcomes of mathematics students, it is considered necessary to develop flipped classroom learning by utilizing technology optimally.

The novelty in this research is to develop relevant learning to accommodate the digitization of learning in the era of industrial revolution 4.0. The development of flipped classroom learning provides media with a variety of learning resources that can be adapted to the student's learning style such as audiovisual media with the integration of GeoGebra utilization as an illustration, visual media in the form of teaching materials that contain materials and practice questions for students, and the existence of other learning resources in the form of supporting internet articles. All media are then expertly tested to produce valid media that can be used in learning. In addition to media for students, this development also produces guidelines for teachers in implementing flipped classroom learning in the form of a learning implementation plan that is also expertly tested so that it is valid for use by teachers. The purpose of this research is to know about how the design of flipped classroom learning development by utilizing google classroom and video conference and also analyzing the validity, practicality, and the effectiveness of flipped classroom learning combined with google classroom and video conference. Validity is measured through expert tests of learning devices and learning media used, practicality is measured through the response of students and teachers on the ease of implementation of flipped classroom learning for mathematics learning, and effectiveness is measured through increased independence and student math learning outcomes.

\section{METHOD}

The type of this research is development research conducted using the Research and Development ( $\mathrm{R}$ $\&$ D) type of research Research and Development (R\&D) are the steps or processes used in developing and or perfecting an existing or new product, and can be accounted for (Yuniarti \& Radia, 2020). The development research was carried out by the ADDIE model procedure. The ADDIE model consists of five steps, namely Analyze, Design, Development, Implementation, Evaluation. The participants in this study consisted of test targets and validators. The validator consists of two learning device experts drawn from a mathematics education lecturer and one teacher at Junior High School and two media experts drawn from an Educational Technology lecturer who is an expert in their field. As for the learning trials using participants 32 students in the junior high schools.

The instruments used include, for the level of validity using an expert validation questionnaire instrument of learning tools consisting of a validated questionnaire for the Lesson Plan, a validation questionnaire for teaching materials, a validated questionnaire for test instruments, and an expert validation questionnaire for learning media with use Likert Scale 1-5. The instruments used for the level of effectiveness include a student learning independence questionnaire with a 1-4 Likert scale, as well as pre-test and post-test. As for the level of practicality, the student and teacher response questionnaire instruments were used with a 1-4 Likert scale. Learning independence questionnaire, student and teacher response questionnaires will be tested for the validity of the content first before being implemented. The grid of research instruments used for measuring the students' mathematics learning outcomes with instruments in the form of pre-test and post-test compiled with Bloom Taxonomy in terms of Coginitif namely remembering (C1), understanding (C2), and analyzing (C3). While the grid of instruments to measure the independence of learning can be seen in the following table:

Table 1. The Grid of Instruments Questionnaire Independent Learning

\begin{tabular}{|c|c|c|c|}
\hline \multirow{2}{*}{ Aspects Assessed } & \multicolumn{2}{|c|}{ Statement Number } & \multirow{2}{*}{$\begin{array}{l}\text { Number of } \\
\text { Statements }\end{array}$} \\
\hline & Positive & Negative & \\
\hline Learning initiative and intrinsic learning motivation & 1,3 & 2 & 3 \\
\hline Diagnosing learning needs & 4 & 5 & 2 \\
\hline Setting learning goals & 6,7 & 8 & 3 \\
\hline Organizing and controlling performance / learning & 9,11 & 10 & 3 \\
\hline Viewing difficulties as challenges & 12 & 13 & 2 \\
\hline
\end{tabular}




\begin{tabular}{|c|c|c|c|}
\hline \multirow{2}{*}{ Aspects Assessed } & \multicolumn{2}{|c|}{ Statement Number } & \multirow{2}{*}{$\begin{array}{l}\text { Number of } \\
\text { Statements }\end{array}$} \\
\hline & Positive & Negative & \\
\hline Finding and utilizing relevant learning resources & 15 & 14 & 2 \\
\hline Choosing and implementing learning strategies & 16,18 & 17,19 & 4 \\
\hline Evaluating learning processes and outcomes & 20 & 21 & 2 \\
\hline Self Efficacy (Self-Concept). & 22 & 23 & 2 \\
\hline Total & & & 23 \\
\hline
\end{tabular}

The data collection methods used in this research consists of quantitative and qualitative data collection. The quantitative data in this study are in the form of expert validation results, the results of independent learning questionnaires, the results of teacher and student response questionnaires, and the acquisition of pre-test and post-test scores. Quantitative data is collected by disseminating related research instruments. While the qualitative data in this study is the result of data in the form of reviews from experts in the form of input, criticism, responses and suggestions according to the questionnaire that has been provided. The data analysis technique used to determine the level of validity is to calculate the percentage for the average which is converted into a feasibility value adapted from the research Sari, (2019). The data analysis technique for the level of product effectiveness begins with a paired sample t-test to test the hypothesis that there is an increase or not in terms of independence and mathematics learning outcomes. Paired t-test is a hypothesis testing method in which the data used are not independent (paired). The characteristics most often found in paired cases are that one individual (research object) gets 2 different treatments (Montolalu \& Langi, 2018). The paired sample t-test was carried out using SPSS 23 software. Then to determine the level of effectiveness in terms of learning independence, it was analyzed with the same average score as the level of practicality, while in terms of learning outcomes it was analyzed using the gain score test

\section{RESULT AND DISCUSSION}

\section{Result}

The development of flipped classroom learning uses the ADDIE stage. The selection of this model is based on the consideration that this model is developed systematically and based on the theoretical foundation of learning design, this model has five steps or stages that are easy to understand and implement. Here is the explanation of the five stages of the ADDIE model. The first is Analyze stage which consists of needs analysis and learning analysis. Analysis of student needs was carried out by interviewing the mathematics subject teacher at Junior High School, while the intended learning analysis was analyzing the applicable curriculum, materials, learning processes, or procedures carried out during the pandemic. The results of the analysis resulted in online learning that students needed appropriate learning strategies accompanied by the use of media that supported students learning independently at home.

The second step is Design stage including the preparation of learning tools and learning media. Learning tools are in the form of lesson plans, teaching materials, and test instruments. Lesson Plan where the learning steps refer to the characteristics of the flipped classroom learning strategy. In the learning implementation plan, learning activities for each meeting are divided into two, namely independent learning (google classroom) for one week before the class schedule, and face-to-face learning activities via video conference (google meet). Teaching materials are arranged with flat-sided building materials which are divided into 5 meetings, namely cubes, beams, prisms, pyramid, and combined flat-sided shapes. Learning media are made using Google Slides which are designed to be as attractive as possible by paying attention to easy access. Learning media in the form of a pdf file consisting of clickable icons containing instructions, teaching materials, learning videos, discussion columns, and reference sections, as follows.

There is a material icon containing the teaching material that has been compiled, then a video icon to go to the learning video that has been uploaded on YouTube, and there is a discussion icon that directly connects students to the discussion column on google classroom. Each media is also equipped with a reference section consisting of 4 icons, where each icon if clicked will connect students to the internet site regarding the material discussed so that it can be additional material for students to learn. In total there are five learning media for five meetings with different designs, so students don't get bored. In addition to the preparation of learning tools and learning media, a class is made in google classroom The Google classroom used is also arranged in an attractive appearance. The background part of google classroom contains a moving animation so it doesn't look monotonous. A moving animation in PNG format is uploaded to the background.

The third is the Development stage, at this stage the prototypes made will be tested by experts and made improvements to the product before it is implemented. The learning tool is tested by a learning device expert. The results of data analysis obtained RPP scores of $88.10 \%$, Teaching Materials $90.00 \%$, and Test Instruments 
90.48\%. Based on the acquisition of learning device expert scores, it can be concluded that the validity of the learning tools is in the very feasible category to be implemented. The learning media is validated by two experts from Educational Technology lecturers. The results of data analysis obtained Percentage average 90.00\%. Based on the scores obtained by the instructional media experts, it can be concluded that the validity of the learning media is in the very feasible category to be implemented. After the validity test, the product was revised with reference to suggestions and comments from experts. The Fourth step is Implementation stage, this stage is the process of implementing flipped classroom learning. The implementation of flipped classroom learning is adjusted to the steps that have been prepared in the Lesson Plan. The self-study activity one week before the face-to-face schedule begins with creating a topic, creating a discussion column, distributing learning media, and providing practice questions.

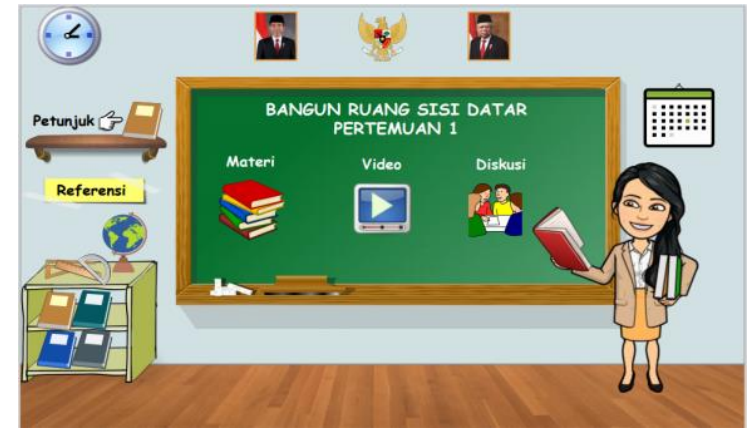

Figure 1. Learning Media
Bangun Ruang Sisi Datar (Kubus) Pertemuan $1 \quad$ :

\begin{tabular}{|c|c|}
\hline (1) Latinan Soal & Tenggat 9 Mar o8 o0 \\
\hline (D) Media Pembelajaran Pertemuan 1 (Kubus) & Diposting tangyal 1922 \\
\hline (2) Kolom Diskusi & Dean 19.10 \\
\hline
\end{tabular}

Figure 2. Google Classroom Topics View

During one week students can watch videos or study material on the material teaching repeatedly adjusted to the speed of understanding each, then if during the independent learning process students experience difficulties, they can ask the discussion column that has been provided. At meeting 1 the students were still adjusting the transition from conventional learning to flipped classroom learning, but at subsequent meetings students were able to adapt and show independence in learning. Students independently discuss with their friends in the discussion column, and the researcher as a teacher will rectify mistakes and confirm the answers to students' questions. Students also independently try to do the practice questions that have been provided in the teaching materials by collecting the results of doing the practice questions on google classroom. After one week of self-study on Google Classroom, followed by face-to-face learning through the Google Meet video conference platform. At face-to-face meetings, the teacher no longer explains the material in detail but stimulates students to suggest what they have learned, emphasize concepts, and discuss the exercises that have been done. In discussing questions, the teacher also provides opportunities for students to present their answers, and other students respond or ask questions. At the end of face-to-face learning, the teacher evaluates by giving quizzes. The final process of the implementation stage is filling out the independent learning questionnaire, student and teacher response questionnaires, and implementing the post-test.

The last stage of development, namely Evaluation, is to revise the product based on suggestions from students and teachers after using flipped classroom learning. The level of validity of flipped classroom learning is seen through the results of expert assessment of learning devices and learning media, while the practicality of developing flipped classroom learning can be seen through student response questionnaires and teacher response questionnaires. Practicality relates to the ease of implementing flipped classroom learning in mathematics learning, is easy for students to understand, makes it easier for students to learn more fun, attracts students' attention, and is easy for teachers to use. Through the student response questionnaire, it was obtained an average practicality score of 3.22 which was included in the high practicality category, while the teacher response questionnaire analysis obtained an average score of the practicality of learning flipped classroom was 3.70, with the practicality category very high. In terms of effectiveness, it is necessary to test the hypothesis first to determine whether there are differences in the level of independence and student learning outcomes using the paired t-test. The test was carried out on the learning independence questionnaire data before and after the developed learning. The results of the paired sample t-test of the hypothesis of independent learning using SPSS 23 software. T- test results are obtained amounting to 6,874 with 31 degrees of freedom, so that the alternative hypothesis in this study is accepted, namely learning independence after learning flipped classroom by utilizing google classroom is better than before implementing flipped classroom learning. Paired sample t-test was also carried out on students' pre-test and post-test data, from the test results using SPSS 23. The t test amounting to 9,997 with 31 degrees of freedom, so that the alternative hypothesis in this study is accepted, namely student learning outcomes after learning flipped classroom by utilizing google classroom is better than before 
implementing flipped classroom learning. The results of the hypothesis test show that the independence and learning outcomes of mathematics after learning that are developed are better than before implementing learning. The level of effectiveness or the level of increased learning independence is seen through the comparison of the average score while the mathematics learning outcomes are through the gain-score test. By analyzing the response to the learning independence questionnaire before and after learning flipped classroom, it was found that the increase in the level of learning independence from 9 aspects can be seen in the following chart:

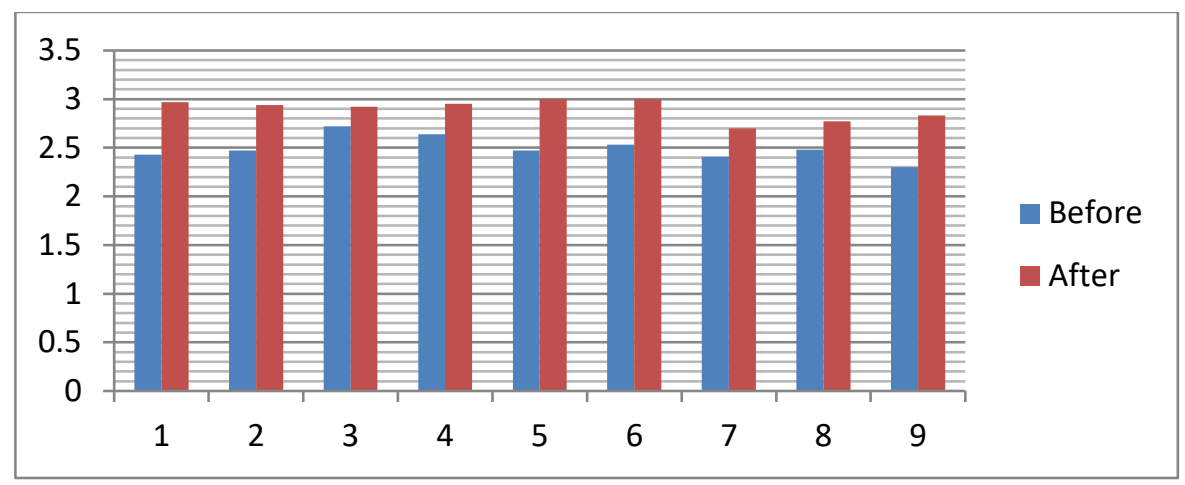

Figure 3. Chart of the Level of Independent Learning Before and After Learning

Figure 3 is a picture of the improvement of each measured aspect, of which there are 9 aspects, namely 1. Learning initiative and intrinsic learning motivation, 2. Diagnosing learning needs, 3. Setting learning goals, 4. Organizing and controlling performance / learning, 5. Viewing difficulties as challenges, 6. Finding and utilizing relevant learning resources, 7. Choosing and implementing learning strategies, 8. Evaluating learning processes and outcomes, and 9. Self Efficacy (Self-Concept). If viewed from the overall average there is an increase of 0.41 where the level of independent learning before learning is in the low category with an average score of 2.49, while after learning it gets an average of 2.90 with the high category. So it can be concluded that flipped classroom learning is effective in terms of increasing student learning independence. To determine the increase in mathematics learning outcomes before and after implementing the developed learning, it was carried out with the consideration of the gain score test score. The analysis results show that the gain score obtained is 0.44 in the moderate category, so it can be concluded that there is an increase in student learning outcomes in the moderate category and the learning developed in the category is quite effective in terms of improving student mathematics learning outcomes.

During the learning flipped classroom being developed, the positive response of students during the learning process also indicates that learning flipped classroom is interesting and provides benefits for students. Learning flipped classroom makes short class learning times more effective and students become more stimulated to develop their abilities (Elfeky \& Masadeh, 2020; Tse et al., 2019). The activities in the classroom are completely filled with discussion activities that require student participation in forming perfect knowledge, so the existence of the teacher in the classroom is only a facilitator (Kurtz et al., 2014; Lin et al., 2021). The learning media used also attracts students' attention because it utilizes technology, is easy to use, practical and there are also learning videos that can increase student understanding (Amali et al., 2020; Gabriele et al., 2016). The instructional video is accompanied by GeoGebra media to make the material look more real through threedimensional illustrations such as the diagonal of the space on the cube, the diagonal plane on the beam, etc. Learning media based on information and communication technology are deemed suitable in this era of rapid technological advancement, with the presence of media it can make students more motivated to learn because abstract things can be concrete and complex things can be simplified (Priantini, 2020; Satyawan, 2018; Van Alten et al., 2019). ICT supports constructivist pedagogy, where pupils use technology to explore and reach the understanding of mathematical concepts, which specifically enhances students' understanding of basic concepts (Baya'a et al., 2019; Leatherman \& Cleveland, 2020). So that the use of technology in learning can improve the understanding of students' mathematical concepts.

Google Classroom is a newly recognized, innovative, and one of the best online platforms for learning and teaching (Ali \& Maksum, 2020; Subandi et al., 2018). Online learning platforms such as Google Classroom provide flexibility in scheduling, eliminate travel expenses, and can reach out to anyone who has access to it (AlMaroof \& Al-Emran, 2018; Albashtawi \& Al Bataineh, 2020). So google classroom becomes a very useful platform in the era of revolution 4.0 and pandemic covid 19. The use of google classroom improves the effectiveness of flipped classroom learning in case 1) Materials are distributed to students systematically so that they can be re-studied at any time, 2) Student discussion results are stored in the discussion column, 3) Students can collect assignments in one place so that teachers are easy to correct, 4) Teachers can easily provide feedback 
from the work done, 5) Teachers can monitor students who collect assignments, both in terms of quantity of accumulated quantities or in terms of punctuality (Albashtawi \& Al Bataineh, 2020; Guswara, 2020).

Flipped classroom has an irreplaceable advantage in the modern teaching. It uses videos to present teaching content, which provides new ideas for innovation of learning methods and breaks the space limitation of teaching (Li et al., 2018; Teng, 2019). Flipped classroom is suitable to increase students' learning independence, because in accordance with its characteristics, the focus of student knowledge development by self-learning first. The flipped classroom learning model using e-learning media also can improve student learning outcomes because of its effectiveness (Ahmed \& Indurkhya, 2020; Rahmelina et al., 2019; Van Alten et al., 2019). The implications of this research are the increasing independence of learning and student math learning outcomes through the development of flipped classroom learning that has been conducted. Seeing the benefits of implementing flipped classroom strategies shows that the contribution of this research is to make scientific contributions about learning strategies that are worth implementing in the era of revolution 4.0 and able to improve the independence and students math learning outcomes so that it can be used as a reference for educators to learn in the classroom. Recommendations for future researchers are to develop flipped classroom learning with different platforms like Edmodo, Schology, Moodle, etc, or use more varied learning media. Researchers can also develop other types of blended learning in addition to flipped classroom such as face to face driver, rotation, flex, etc.

\section{CONCLUSION}

The results of flipped classroom learning development by utilizing google classroom and video conference using ADDIE development model meet valid, practical and effective criteria on math learning. It can be concluded that the development of flipped classroom learning by utilizing google classroom and video conference can increase the independence and student's mathematics learning outcomes.

\section{REFERENCES}

Adedoyin, O. B., \& Soykan, E. (2020). Covid-19 Pandemic and Online Learning: The Challenges and Opportunities. In Interactive Learning Environments. https://doi.org/10.1080/10494820.2020.1813180.

Ahmed, M. M. H., \& Indurkhya, B. (2020). Investigating Cognitive Holding Power and Equity in the Flipped Classroom. Heliyon, 6(8). https://doi.org/10.1016/j.heliyon.2020.e04672.

Akay, H., \& Kim, S.-G. (2020). Measuring Functional Independence in Design with Deep-Learning Language Representation Models. Procedia CIRP, 91. https://doi.org/10.1016/j.procir.2020.02.210.

Al-Maroof, R. A. S., \& Al-Emran, M. (2018). Students Acceptance of Google Classroom: An Exploratory Study Using PLS-SEM Approach. International Journal of Emerging Technologies in Learning (IJET), 13(06), 112-123. https://doi.org/10.3991/ijet.v13i06.8275.

Albashtawi, A. H., \& Al Bataineh, K. B. (2020). The Effectiveness of Google Classroom among EFL Students in Jordan: An Innovative Teaching and Learning Online Platform. International Journal of Emerging Technologies in Learning, 15(11), 78-88. https://doi.org/10.3991/IJET.V15I11.12865.

Ali, M. K., \& Maksum, H. (2020). Utilization of E-Learning-Based ICT Learning Using the Google Classroom Application During the COVID-19 Pandemic. Journal of Education Research and Evaluation, 4(4), 373. https://doi.org/10.23887/jere.v4i4.29181.

Amali, L. N., Zees, N., \& Suhada, S. (2020). Motion Graphic Animation Video as Alternative Learning Media. Jambura Journal of Informatics, 2(1). https://doi.org/10.37905/jji.v2i1.4640.

Anitha Kumari, T., Hemalatha, C. H., Subhani Ali, M., \& Naresh, R. (2020). Survey on Impact and Learning's of the Online Courses on the Present Era. Procedia Computer Science, 172, 82-91. https://doi.org/10.1016/j.procs.2020.05.167.

Anjelina, Y., \& Mawardi, M. (2021). Validity of Flipped Classroom Based on Guided Inquiry in Chemical Bonding Materials Using Edmodo. International Journal of Progressive Sciences and Technologies, 27(1), 29-34. https://doi.org/10.52155/ijpsat.v27.1.3023.

Baya'a, N., Daher, W., \& Anabousy, A. (2019). The Development of In-Service Mathematics Teachers' Integration of ICT in a Community of Practice: Teaching-In-Context Theory. International Journal of Emerging Technologies in Learning, 14(1), 125-139. https://doi.org/10.3991/ijet.v14i01.9134.

Bui, V. H., \& Do Van Dung. (2019). Development of Vietnamese Vocational Education Teachers to Adapt the Industrial Revolution 4.0. Asian Journal of Interdisciplinary Research, 2(4), 1-7. https://doi.org/10.34256/ajir1941.

Dziuban, Graham, C. R., Moskal, P. D., Norberg, A., \& Sicilia, N. (2018). Blended Learning: The New Normal and Emerging Technologies. International Journal of Educational Technology in Higher Education, 
15(3), 1-16. https://educationaltechnologyjournal.springeropen.com/articles/10.1186/s41239-017-00875.

Elfeky, A. I. M., \& Masadeh, T. S. Y. (2020). Advance Organizers in Flipped Classroom Via E-Learning Management System and the Promotion of Integrated Science Process Skills. Thinking Skills and Creativity, 35. https://doi.org/10.1016/j.tsc.2019.100622.

Fakhriyah, F. (2014). Penerapan Problem Based Learning dalam Upaya Mengembangkan Kemampuan Berpikir Kritis Mahasiswa. Jurnal Pendidikan IPA Indonesia, 3(1), 95-101. https://doi.org/10.15294/jpii.v3i1.2906.

Felver, J. C., Celis-de Hoyos, C. E., Tezanos, K., \& Singh, N. N. (2016). A Systematic Review of MindfulnessBased Interventions for Youth in School Settings. Mindfulness, 7(1), 34-45. https://doi.org/10.1007/s12671-015-0389-4.

Fernández-Gutiérrez, M., Gimenez, G., \& Calero, J. (2020). Is the Use of ICT in Education Leading to Higher Student Outcomes? Analysis from the Spanish Autonomous Communities. Computers and Education, 157, 103969. https://doi.org/10.1016/j.compedu.2020.103969.

Fitriyana, N., Wiyarsi, A., Ikhsan, J., \& Sugiyarto, K. H. (2020). Android-Based-Game and Blended Learning in Chemistry: Effect on Students' Self-Efficacy and Achievement. Jurnal Cakrawala Pendidikan, 39(3), 507-521. https://journal.uny.ac.id/index.php/cp/article/view/28335/pdf_1.

Foldnes, N. (2016). The Flipped Classroom and Cooperative Learning: Evidence from a Randomised Experiment. SAGE Journal, 17(1). https://doi.org/10.1177\%2F1469787415616726.

Gabriele, K. M., Holthaus, R. M., \& Boulet, J. R. (2016). Usefulness of Video-Assisted Peer Mentor Feedback in Undergraduate Nursing Education. Clinical Simulation in Nursing, 12(8), 337-345. https://doi.org/10.1016/j.ecns.2016.03.004.

Guswara, A. M. (2020). The Contribution of Google Classroom Application and Motivation to The Learning Outcomes of Web Programming. Educational Technology, 4(4), 1-9. https://doi.org/10.23887/jet.v4i4.29896.

Hobri, Septiawati, I., \& Prihandoko, A. C. (2018). High-Order Thinking Skill in Contextual Teaching and Learning of Mathematics Based on Lesson Study for Learning Community. International Journal of Engineering and Technology(UAE), 7(3), 1576-1580. https://doi.org/10.14419/ijet.v7i3.12110.

Indah Septiani, A. nisa N. S., Septiani, I., Rejekiningsih, T., Triyanto, \& Rusnaini. (2020). Development Of Interactive Multimedia Learning Courseware to Strengthen Students' Character. European Journal of Educational Research, 9(3), 1267-1279. https://doi.org/10.12973/eu-jer.9.3.1267.

Irodah, P. A., Khoiriyah, H., Batul, Z., Maulidasilvi, R., Setyawan, D., \& Nyono, N. (2020). Revolusi Industri 4. 0 : Tranformasi Media Belajar E-Learning Menggunakan Framework. Prosiding Seminar Nasional V 2019, 2015, 368-377. http://research-report.umm.ac.id/index.php/psnpb/article/view/3616.

Istikomah, \& Usman. (2019). Relationship Student Attitude, Learning Independence, and Learning Style with Learning Outcomes. SSRN Electronic Journal. https://doi.org/10.2139/ssrn.3415256.

Jogezai, N. A., Baloch, F. A., Jaffar, M., Shah, T., Khilji, G. K., \& Bashir, S. (2021). Teachers' Attitudes towards Social Media (SM) Use in Online Learning Amid the Covid-19 Pandemic: The Effects of SM Use by Teachers and Religious Scholars During Physical Distancing. Heliyon, 7(4). https://doi.org/10.1016/j.heliyon.2021.e06781.

Kergroach, S. (2017). Industry 4.0: New Challenges and Opportunities for the Labour Market. Foresight and STI Governance, 11(4), 6-8. https://doi.org/10.17323/2500-2597.2017.4.6.8.

Kurniawati, M., Santanapurba, H., \& Kusumawati, E. (2019). Penerapan Blended Learning Menggunakan Model Flipped Classroom Berbantuan Google Classroom dalam Pembelajaran Matematika SMP. EDU-MAT: Jurnal Pendidikan Matematika, 7(1), 8-19. https://doi.org/10.20527/edumat.v7i1.6827.

Kurtz, G., Tsimerman, A., \& Steiner, O. (2014). The Flipped Classroom Answer to Future Learning? European Journal of Open, Distance and E-Learning, 17(2). https://doi.org/10.2478/eurodl-2014-0027.

Leatherman, J. L., \& Cleveland, L. M. (2020). Student Exam Performance in Flipped Classroom Sections is Similar to That in Active Learning Sections, and Satisfaction with the Flipped Classroom Hinges on Attitudes toward Learning from Videos. Journal of Biological Education, 54(3), 328-344. https://doi.org/10.1080/00219266.2019.1575266.

Li, J., Zhang, X., \& Hu, Z. (2018). The Design and Application of Flip Classroom Teaching Based on Computer Technology. International Journal of Emerging Technologies in Learning, 13(10), 95-107. https://doi.org/10.3991/ijet.v13i10.9453.

Lin, Y.-N., Hsia, L.-H., \& Hwang, G.-J. (2021). Promoting Pre-Class Guidance and In-Class Reflection: A SQIRC-Based Mobile Flipped Learning Approach to Promoting Students' Billiards Skills, Strategies, Motivation and Self-Efficacy No Title. Computers \& Education, 160. https://doi.org/10.1016/j.compedu.2020.104035.

Liu, Y., Wang, L., Mammadov, M., Chen, S., Wang, G., Qi, S., \& Sun, M. (2021). Hierarchical Independence 
Thresholding for Learning Bayesian Network Classifiers. Knowledge-Based Systems, 212. https://doi.org/10.1016/j.knosys.2020.106627.

Mills, K., Roper, F., \& Cesare, S. (2021). Accelerating Student Learning in Communication and Research Skills: The Adoption of Adaptive Learning Technologies for Scenario-Based Modules. Technology, Change and the Academic Library, 75. https://doi.org/10.1016/B978-0-12-822807-4.00007-5.

Montolalu, C., \& Langi, Y. (2018). Pengaruh Pelatihan Dasar Komputer dan Teknologi Informasi bagi GuruGuru dengan Uji-T Berpasangan (Paired Sample T-Test). D'CARTESIAN, 7(1), 44. https://doi.org/10.35799/dc.7.1.2018.20113.

Nonthamand, N. (2020). Guideline to Develop an Instructional Design Model Using Video Conference in Open Learning. International Journal of Emerging Technologies in Learning, 15(3), 140-155. https://doi.org/10.3991/ijet.v15i03.10842.

Nuswowati, M., Susilaningsih, E., Ramlawati, \& Kadarwati, S. (2017). Implementation of Problem-Based Learning with Green Chemistry Vision to Improve Creative Thinking Skill and Students' Creative Actions. Jurnal Pendidikan IPA Indonesia, 6(2), 221-228. https://doi.org/10.15294/jpii.v6i2.9467.

Prasasti, T. I., Solin, M., \& Hadi, W. (2019). The Effectiveness of Learning Media Folklore Text of North Sumatera Based on Blended Learning by 10th Grade Students of Vocational High SchoolH arapan Mekar-1 Medan. Bir-Le Journal, 4(2). https://doi.org/10.33258/birle.v2i4.548.

Priantini, D. A. (2020). The Development of Teaching Video Media Based on Tri Kaya Parisudha in Educational Psychology Courses. Journal of Education Technology, 4(4). https://doi.org/10.23887/jet.v4i4.29608.

Qingqing, H. U. (2016). Research on Flipped Classroom Design and Implication Based on Edmodo Platform. 2016 Eighth International Conference on Measuring Technology and Mechatronics Automation (ICMTMA), 528-532. https://doi.org/10.1109/ICMTMA.2016.131.

Rahmelina, L., Firdian, F., Maulana, I. T., \& Aisya, H. (2019). The Effectiveness of the Flipped Classroom Model Using E-Learning Media in Introduction to Information Technology Course. International Journal of Emerging Technologies in Learning, 14(44 1), 148-162. https://onlinejournals.org/index.php/i-jet/article/view/10426.

Sari, T. K. A. (2019). Pengembangan Media Pembelajaran Matematika Berbasis Adobe Flash di SD Negeri 4 Metro Barat.

Satyawan, V. (2018). The Use of Animation Video to Teach English at Junior High School Students. Jellt (Journal of English Language and Language Teaching), 2(2), 89-96. https://doi.org/10.36597/jellt.v2i2.3277.

Sefriani, R., Sepriana, R., Wijaya, I., \& Radyuli, P. (2021). Blended Learning with Edmodo: The Effectiveness of Statistical Learning during the COVID-19 Pandemic. International Journal of Evaluation and Research in Education, 10(1), 293-299. https://doi.org/10.11591/ijere.v10i1.20826.

Shahroom, A. A., \& Hussin, N. (2018). Industrial Revolution 4.0 and Education. International Journal of Academic Research in Business and Social Sciences, 8(9). https://doi.org/10.6007/IJARBSS/v8i9/4593.

Stojanović, J., Petkovic, D., Alarifi, I. M., Cao, Y., Denic, N., \& Ilic, J. (2021). Application of Distance Learning in Mathematics through Adaptive Neuro-Fuzzy Learning Method. Computers \& Electrical Engineering, 93. https://doi.org/10.1016/j.compeleceng.2021.107270.

Subandi, S., Choirudin, C., Mahmudi, M., Nizaruddin, N., Hermanita, H., \& Hermanita, H. (2018). Building Interactive Communication with Google Classroom. International Journal of Engineering \& Technology, 7(2.13), 460-463.

Syahroni, M. W., Dewi, N. R., \& Kasmui. (2016). The Effect of Using Digimon (Science Digital Module) with Scientific Approach at the Visualization of Students' Independence and Learning Results. Jurnal Pendidikan IPA Indonesia, 5(1), 116-122. https://doi.org/10.15294/jpii.v5i1.5800.

Teng, (Mark) Feng. (2019). The Effects of Video Caption Types and Advance Organizers on Incidental L2 Collocation Learning. Computers \& Education, 142. https://doi.org/10.1016/j.compedu.2019.103655.

Tse, W. S., Choi, L. Y. A., \& Tang, W. S. (2019). Effects of Video-Based Flipped Class Instruction on Subject Reading Motivation. British Journal of Educational Technology, 50(1), 385-398. https://doi.org/10.1111/bjet.12569.

Van Alten, D. C. D., Phielix, C., Janssen, J., \& Kester, L. (2019). Effects of Flipping the Classroom on Learning Outcomes and Satisfaction: A Meta-Analysis. Educational Research Review, 28(June), 1-18. https://doi.org/10.1016/j.edurev.2019.05.003.

Wau, M. P. (2017). Pengaruh Model Problem Based Learning Terhadap Hasil Belajar IPS pada Siswa Kelas IV SD Bajawa Kecamatan Bajawa Kabupaten Ngada. Journal of Education Technology, 1(4), 239. https://doi.org/10.23887/jet.v1i4.12860.

Widiasanti, I. (2017). The Role of Universities in Engineer Certification as Quality Assurance of Engineers 
Professionalism. Advanced Science Letters, 23(1), 156-159. https://doi.org/10.1166/asl.2017.7206.

Widyaningrum, H. K., Hasanudin, C., Fitrianingsih, A., Novianti, D. E., Saddhono, K., \& Supratmi, N. (2020). The Use of Edmodo Apps in Flipped Classroom Learning. How is the Students' Creative Thinking Ability? Ingénierie Des Systèmes d Inf., 25(1), 69-74. https://doi.org/10.18280/isi.250109.

Xu, M., David, J. M., \& Kim, S. H. (2018). The Fourth Industrial Revolution: Opportunities and Challenges. International Journal of Financial Research, 9(2), 90-95. https://doi.org/10.5430/ijfr.v9n2p90.

Yen, T.-F. T. F. (2020). The Performance of Online Teaching for Flipped Classroom Based on Covid-19 Aspect. Asian Journal of Education and Social Studies, 57-64. https://doi.org/10.9734/ajess/2020/v8i330229.

Yigzaw, M., Tebekaw, Y., Kim, Y.-M., Kols, A., \& Ayalew, F. (2019). Comparing the Effectiveness of a Blended Learning Approach with a Conventional Learning Approach for Basic Emergency Obstetric and Newborn Care Training in Ethiopia. Midwifery, 78. https://doi.org/10.1016/j.midw.2019.07.014.

Yuniarti, A., \& Radia, E. H. (2020). Development of Comic Mathematics Teaching Materials on Flat-Building Material to Increase Reading Interest in Class IV Elementary School Students. Journal of Education Technology, 4, 415-423. https://doi.org/10.23887/jet.v4i4.30034.

Zainuddin, Z., \& Perera, C. J. (2019). Exploring Students' Competence, Autonomy and Relatedness in the Flipped Classroom Pedagogical Model. Journal of Further and Higher Education, 43(1), 115-126. https://doi.org/10.1080/0309877X.2017.1356916. 